\title{
Consumer Rights, Competition and Intellectual Property Protection Regimes in the EaP Countries at the Cross Roads: EU Requirements and Reality
}

\section{Oksana HOLOVKO-HAVRYSHEVA*}

\begin{abstract}
Unlike the protection of the intellectual property or competition, the cooperation of the EU with the EaP countries in consumer protection matters belongs to the topics which are not prioritized by the bilateral and multilateral cooperation agenda and fora. Rooted in different contractual framework, the cooperation in consumer protection matters, in the cases of the competition and intellectual property rights protection, is linked mainly to the approximation of legislation and regulatory practices used by the EaP countries to fulfil their obligations. This article aims to compare the EaP countries practices dealing with the consumer protection, competition protection and intellectual property protection regimes in order to identify the potential impact the properly ensured competition and effectively enforced intellectual property rights can cause on the level of the consumer protection as an effect of the proper and due approximation of the relevant legislation to the EU standards.
\end{abstract}

Key words: consumer protection, competition, intellectual property, EaP countries, approximation of legislation

JEL Code: K33, O34, N44

\section{Introduction}

The cooperation between the EU and the EaP countries can be traced back to the contractual frameworks of the cooperation with the Soviet Union. After

\footnotetext{
* $\mathrm{PhD}$ in Law, Oksana Holovko-Havrysheva, associate professor of the European Law Department, Ivan Franko National University of Lviv), associate professor of the International and European Law Department, National University "Kyiv-Mohyla Academy", President of the Ukrainian European Studies Association, Ukraine, https://orcid.org/0000-0002-8506-4374, oksana.holovko-havrysheva@lnu.edu.ua
} 
the Soviet Union collapsed in 1991 and newly independent states appeared on the international arena, they developed their own visions and policies towards the European integration, and thus the EU policies towards them developed consequently. The need to face the diverse priorities of the states on the postSoviet space was considered under the Eastern Partnership initiative, focusing especially on the countries bordering the EU directly.

Despite the EaP countries face economic and political difficulties, each of them pursues its own national policy towards the EU. The economic difficulties caused by the internal economic problems and influenced by global economic developments (e.g. unemployment, poor economic climate and distrust in the state authorities) followed by political turbulences (raising authoritarian political regimes, human rights violations, corruption, malfunctioning public administration, frozen conflicts etc.) make the cooperation between them and the EU more complicated.

Nevertheless, ensuring the economic development is an ultimate goal, which is prioritized both by the EaP countries government and their citizens. The support for economic development of the EaP countries as an opportunity to maintain peace and prosperity in Europe in wider terms is the undergrounding idea of the ENP and remains a key subject-matter of the bilateral cooperation between the EU and the EaP countries.

Beyond the trade and liberalization of economic cooperation as the key instruments, ability of fostering the economic development and boosting national economies, the competition protection and protection of the intellectual property rights are very often considered as important contributors to the stable and sustainable economic progress, whereas the consumer protection, not the consumption as such, is not considered in the debate on ensuring stable economic development. In fact, both intellectual property protection and competition protection regimes aim to support consumers and their welfare, however the levels of their operation and instruments used are different. An efficient and effective intellectual property regime helps consumers to establish the link between the product or service and the enterprise it produces, the region and the right company it comes from. In a wider perspective it ensures the right choice according to the consumer's will and enables a certain level of the protection from unfair marketing and misleading practices, which mainly available to 
businesses or the state and not to the consumers. The competition law operates as well on business-to-business and business-to-state levels, since it deals primarily with distortion of competition by competitors on the market. Although the competition law helps consumers to get to the market through detecting and sanctioning anti-competitive practices, including cartels, the abuse of market power, uncontrolled mergers and bid-rigging in public procurement (law enforcement instruments) and advocacy instruments, in the cases of the violation of competition the consumer protection nexus is not dominating the debate as well.

The intellectual property rights protection regime as well as the competition protection and consumer protection regimes developed reflecting the peculiarities of real economy in contrast to the digital economy which is developing rapidly. Thus, classical consumer rights as the right to replace, return, repair and refund gain new forms (such as the consumer's right to information, the right to remedy and the right to compensation for damage) in the virtual economic environment paving the way to the key positions in the consumer rights lists.

The protection of intellectual property and effective enforcement of intellectual property rights was a subject to the framework regulation contained in the Agreement between the European Economic Community and the European Atomic Energy Community and the Union of Soviet Socialist Republics on trade and commercial and economic cooperation (hereafter - the Agreement 1989) and remains today a priority for the bilateral cooperation between the EU and the EaP countries. The competition and consumer protection as well as the approximation of the domestic legislation to the EU standards have been included in the cooperation framework already when the partnership and cooperation agreements were negotiated, concluded and implemented.

The new contractual cooperation framework - the Association Agreements with Georgia, Moldova and Ukraine and the new generation partnership and cooperation agreement with Armenia contain extended commitments in these areas. Moreover, the commitments there are genuinely linked to the international obligations arising from different international instruments like WTO and WIPO. Whereas all EaP countries joined the WIPO (Ukraine and Belarus became members already in 1970, whereas Georgia and Moldova accessed the WIPO in 1991, Armenia joined the WIPO in 1993 and 
Azerbaijan accession to the WIPO took place in 2005), the history with the WTO membership is more complicated: Georgia has been the WTO member since 2000, the Republic of Moldova joined the WTO in 2001; Armenia accessed the WTO in 2003 and Ukraine joined the WTO in 2008. Belarus and Azerbaijan established the accession working parties in 1993 and 1997 respectively, both being in the middle of the WTO accession process with more progress for Belarus, where the last accession working party meeting was conducted in 2019.

According to the Global Innovation Index in 2020 the EaP countries are coming closely to the middle scores with Ukraine as a for-runner on 45-th place, followed by Moldova at 59, Armenia at 61, Georgia at 63, Belarus at 64 and Azerbaijan at 82 positions respectively, however their economic and innovation potential remains largely unused (Global Innovation Index, 2020).

\section{Literature review}

The research on the interconnections between the intellectual property rights and consumer protection regimes on the interdependencies between the consumer competition and consumer protection as well as on the links between the intellectual property rights regimes and competition protection is presented in the academic debate (e.g. Stazi, 2009; Mathis, 2015; Torti, 2016 and others), but as Hovenkamp (2014) rightfully noted that relatively little publications focus on the intersections between the competition, consumer and intellectual property rights protection and address very often the economic dimensions of this complex interplay when the role of competition law and intellectual property protection law in the promotion of the economic welfare is addressed. The legal analysis of the intellectual property protection, consumer protection and competition protection regimes are rarely conducted as well. This research focuses on the provisions of the agreements concluded between the EU and the $\mathrm{EaP}$ countries, the wider international regulatory framework of Belarus, Azerbaijan, Georgia, Moldova, Ukraine and Armenia on the above-mentioned issues accompanied by the analysis of the domestic legislation of Belarus, Azerbaijan, Georgia, Moldova, Ukraine and Armenia. 


\section{Data and Methodology}

The aim of this paper is to compare the EaP countries practices dealing with the consumer protection, competition protection and intellectual property protection regimes in order to identify the potential impact the properly ensured competition and effectively enforced intellectual property rights can cause on the level of the consumer protection as an effect of the proper and due approximation of the relevant legislation to the EU standards.

This contribution is based on the desk-top research of the available legislative framework for the intellectual property, consumer and competition protection regulation in the EaP countries focusing primarily upon the contractual framework regulating the cooperation between the EU and Belarus, Azerbaijan, Georgia, Moldova, Ukraine and Armenia in the above-mentioned areas. It includes the comparison of national constitutional provisions regarding the application of international treaties and domestic legislation on intellectual property rights, consumer and competition protection in the $\mathrm{EaP}$ countries aiming to give the outlook on the current state of the cooperation between these countries and the EU. The paper's structure is linked to the analysis of the cooperation between the EU and Belarus, Azerbaijan, Georgia, Moldova, Ukraine, and Armenia in these areas and their approaches to the implementation of the contractual obligations arising from their most recent contractual framework with the EU.

\section{Cooperation between the $E U$ and Belarus in the intellectual property, competition and consumer protection: general characteristics}

After Belarus became independent in 1991, the mutual relations between it and the EU were established on the fact of the recognition of Belarus independence by the European Economic Community, following at first the cooperation paradigm deployed by the EU to deal with the CIS countries. However, after 1994 when Aleksandr Lukashenko became the president of the country, the cooperation between the EU and Belarus worsened. In 1995, after the President Aleksandr Lukashenko came into power, the EU and Belarus negotiated and signed the Partnership and Cooperation Agreement, which never entered into force due to its missing ratification by the EU because of the 
lacking commitment of the Belorussian authorities to the democracy, rule of law and civic engagement.

The contemporary relations between the EU and Belarus are based on the Agreement 1989 and on the Council Conclusions (Council Conclusions, 2016) which contain the framework of rules for the parties mainly in the area of trade. Continuous difficulties with the maintenance of democratic institutions, rule of law and civic participation in Belarus, the EU follows the policy of critical engagement in bilateral relations, maintaining the necessary cooperation in economic and social relations with lacking adequate dialogue on the governmental level. After the presidential elections in 2020 the EU increased the sanction coverage in response to constant and severe violations of human rights in the country.

The USSR Economic Cooperation Agreement 1989 provided the mostfavourite nation treatment in commercial and trade relations, as well as enhanced cooperation in customs matters, trade-related taxation, trade-related transfers and payments and introduced the prohibition of quantitative restrictions on import of goods originating from the EU. This agreement highlights areas of mutual interest for the cooperation between the counterparts, especially avoiding the trade conflicts and imposing the safeguard measures. The provisions of this Agreement contain framework regulations and commitments, thus require comprehensive implementation efforts from the counterparts.

Having economic and commercial cooperation as the primary goal of the regulation, the Agreement 1989 does not deal either with the competition protection matters or with the consumer protection issues. The approximation of the legislation and regulatory practices are excluded as well from the scope of the regulation. Although the Agreement 1989 does not cover the competition and the consumer protection dimensions of the bilateral relations, in area of the intellectual property regulation the parties agreed to provide the adequate protection of the industrial, commercial and intellectual property rights according to the relevant international commitments at the interstate level followed by the intent to ensure the due IPR protection while conducting business inside the Contracting Parties. The implementation of the Agreement 1989 is based on the constitutional provisions, which determine the applicability of international legal norms in the domestic legal order and 
contains the prohibition of conclusion of international treaties if they contradict the Constitution (the Constitution of Belarus, 1994, Art.8).

The Constitution establishes the priority of recognized principles of international law over the domestic legislation, leaving open the debate on the legal status of the international law in the domestic legal order. Unlike constitutions of other EaP countries, the Constitution of Belarus regulates its cooperation and membership in the international organizations and sets clearly the right to enter the international organizations as well as to leave them (the Constitution of Belarus,1994, Art.8, Art.61). These constitutional provisions form, in fact, the legal basis for the cooperation between Belarus and the Eurasian Economic Union, as well as they are applicable to the relations between Belarus and the EU.

The contemporary cooperation between Belarus and the EU in the area of the intellectual property rights, competition and consumer protection varies: whereas the cooperation in the area of the intellectual property rights protection develops in the framework of the cooperation with the WIPO, the competition and consumer protection areas remain more fragmented. Since Belarus is not the WTO member, the application of the WTO provisions in the relations between the EU and Belarus in trade and trade-related matters is actually based on Agreement 1989, which contains only framework obligations for parties so far.

The intellectual property rights protection regime in Belarus is based on the Soviet legacy, where the legal regime for industrial property, commercial property and intellectual property and related rights is regulated by laws and is accompanied by secondary legislation. Besides globally recognized commitments in the IPR protection, Belarus at the regional level holds full membership at the Eurasian Economic Union (EEU). Within the EEU regulatory framework on Belarus is a member to IPR-relevant commitments arising inter alia from the EEU Protocol on the protection and enforcement of intellectual property rights and the Agreement on a single customs register of intellectual property objects of the Member States of the Eurasian Customs Union, the EEU Agreement on Cooperation in the Area of Legal Protection of Intellectual Property and on Establishment of Interstate Council on Legal Protection of Intellectual Property and the Eurasian Patent Convention. 
The competition protection regime in Belarus in the global dimension is linked to the UNCTAD standards on the competition. At the regional level the impact of the EEU membership is essential: Belarus signed the Annex 19 to the Treaty on the Eurasian Economic Union - Protocol on General Principles and Rules of Competition, as well as it recognizes the EEU rules and practices for investigating the competition in the EEU-relevant transboundary markets. Its recent domestic competition protection legislation is based on the Law «On the counteraction to monopolistic activities and promotion of competition» (Law of the Republic of Belarus nr. 94-3, 2013), which was adopted in 2013 and modernizes slightly the competition protection regime in the country.

The consumer protection is regulated by the national Consumer Protection Act (Law of the Republic of Belarus nr 90-z, 2001), which contains consumer rights regime, which reflects the Soviet traditions where the consumer rights enforcement depended on the domestic civil and commercial law legislation. Unlike the intellectual property and competition protection regimes, the international dimension of the consumer protection is not that much developed. There is lack of systematic cooperation between the EU and Belarus in this area as well, however the EU acts through external cooperation project, e.g. examining the possibility to align the consumer rights protection on financial markets to the EU standards within the Twinning project with the National Bank of Belarus.

Thus, the cooperation between the EU and Belarus in this area follows the general path of the policy of critical engagement at the side of the European Union. The cooperation in the areas of intellectual property rights and competition protection has become more complicated due to Belarus membership in the EEU, its adherence to the standards developed within this framework. Unlike to the cooperation in competition and IPR matters Belarus' international commitments for the area of the consumer protection is available more flexibility and space for the development of the cooperation with the EU. Unlike other EaP countries, Belarus does not have a unilateral commitment to align its legislation to the EU standards, thus the compatibility of the Belarussian legislation and its alignment to the EU acquis is not discussed in the context of the approximation discourse. The widening of the cooperation perspectives with Belarus in these selected areas is nevertheless subject to the 
democracy, rule of law and human rights discourses and depend very much upon the decrease of the authoritarism in Belarus.

\section{General framework of the relations between the EU and Azerbaijan in the intellectual property, competition and consumer protection matters}

The EU-Azerbaijan relations started to develop after the country became independent in 1991. Being promising at the start, the country though started to introduce the restrictions and limitations to human rights and civil society institutions and the EU faced the need to find a new denominator for the bilateral cooperation preventing its stagnation.

In 2004 Azerbaijan joined the European Neighbourhood Policy and in 2009 it became the EaP member. The contractual relations between the EU and Azerbaijan are more extensively developed as compared to Belarus. The EU and Azerbaijan signed a visa facilitation and readmission agreement in 2013. In 2014 countries signed a Protocol to the PCA allowing Azerbaijan to participate in selected EU programs and agencies.

Despite the cooperation between the EU and Azerbaijan is quite active, legally it is based on the Partnership and Cooperation Agreement (hereafter PCA 1996), signed in 1996 and came in force in 1999. The national policy on the issues of the approximation of the domestic legislation is linked to the constitutional provisions which determine that state powers in the country can only be limited either by law or by the international treaty to which Azerbaijan is a party (the Constitution of the Republic of Azerbaijan: Art. 7(II)). It also stipulates those international treaties form integral part of the international order of the country (the Constitution of the Republic of Azerbaijan: Art. 148(II)) and in case of contradiction between the domestic legislation (except the Constitution itself and legal acts adopted by referenda) and the international treaties the last shall prevail (the Constitution of the Republic of Azerbaijan (1995): Art. 151). The Constitution of Azerbaijan does not contain the provisions on the direct applicability of international treaties. In 2006 the draft National Programme on Legal Approximation of the Legislation of the Republic of Azerbaijan with the EU Acquis for Implementation of the Partnership and Cooperation Agreement between the European Union and 
Member States and the Republic of Azerbaijan was proposed, however the approximation results are not presenting the holistic picture as to the practices applied and results achieved. Being a key strategic partner for the EU on energy sector, in 2017 the EU and Azerbaijan started negotiations on a new cooperation and partnership agreement initiated by Azerbaijan.

The cooperation in the intellectual property rights matters is regulated by Art.42 of the PCA 1996 containing framework obligation to ensure the intellectual property protection by Azerbaijan as the ultimate bilateral cooperation goal. In the area of consumer protection, the parties' commitments are of similar nature (PCA, 1996: Art. 66) defining fostering of the cooperation as a general cooperation goal. The cooperation between the EU and Azerbaijan in competition matters is not separately regulated by the PCA as focal point of interests, however all these issues are covered by article 43 of the PCA, which contains the provisions of legislatory and regulatory approximation between the EU and Azerbaijan.

Despite Azerbaijan's intellectual property protection regime is linked to the membership in WIPO, the enforcement of the intellectual property rights in the country is reported to be poor. The cooperation with the CIS countries in these matters is crucial: Azerbaijan has been a member of the Eurasian Patent Convention and the Eurasian Patent Organization since 1995 as well as a member of the Agreement on Mutual Preservation of Inter-State Secrets in the Area of Legal Protection of Inventions and the Agreement on Cooperation in the Repression of Offenses in the Field of Intellectual Property, governing the cooperation among the EEU countries in the area of intellectual property protection on the post-Soviet area. Thus, the country needs a strategy to be developed as to the compatibility of the EEU's and EU standards to be complied with.

In Azerbaijan, the consumer and competition protection legislation are based upon Soviet legal tradition. Azerbaijan's consumer protection legislation is based on the national Consumer Protection Act of 1995 (Law of the Republic of Azerbaijan nr. 1113, 1995), being not aligned with the EU requirements on the consumer protection expressis verbis in its text. The competition protection legislation is based on rules, which were also developed in 1993-1995, being substantially amended, e.g. in 2009, when the substantial powers in the area 
competition and consumer protection were given to a single institution - the State Service for Antimonopoly Policy and Protection of Consumers' Rights under the Ministry of Economic Development of the Azerbaijan Republic, uniting the consumer protection and fight against competition distortion under the auspices of a sole regulator.

To sum up, Azerbaijan's is not EEU full member, its cooperation with the EU is more advanced even so there are difficulties that arise on the political level. Moreover, Azerbaijan follows selective and pragmatic approach towards the cooperation with the EU in sectoral matters. Such situation seems to be caused by its internal political discussions about Azerbaijan's future relations with the EU and the EEU, where the latter are key political actors in the region.

\section{The cooperation in intellectual property, competition and consumer protection between the EU and Associated Countries}

Georgia, Moldova and Ukraine, despite having different priorities in their national political discourses with the regard to the relations with European Union, have a similar legal framework for their bilateral cooperation - the Association Agreements. Georgia and Moldova signed and ratified the Association Agreement in 2014 without hard societal challenges inside the countries. The signature of the Association Agreement between the EU and Ukraine took place in 2014 after the Euromaidan Revolution, which was followed by the annexation of the Crimea by the Russian Federation. At first the Deep and Comprehensive Free Trade Area (hereafter DCFTA) provisions were provisionally applied in the relations between the EU and Ukraine. The complete ratification of the EU-Ukraine Association Agreement took place in 2017, thus the legal framework for the relations between the EU and Georgia, Moldova and Ukraine became similarly organized. All these Agreements include provisions on establishing a free trade area with the EU and so-called approximation clauses, which include unilateral obligations of the Associated countries to approximate their legislation to the EU, including intellectual property rights, competition and consumer protection.

The cooperation between the EU and the associated countries in the area of intellectual property rights is regulated expressis verbis in the Association 
Agreements in quite detailed manner, highlighting the importance of the effective enforcement of the intellectual property rights in the bilateral economic relations for the proper functioning of the DCFTA. It is also openly linked to legislative and regulatory approximation discourses and practices, regulated in general terms by the Association Agreements (e.g. in clauses defining the gradual integration to the EU Internal Market for all countries as a particular association aim (EU-Georgia AA, 2014, Art.2 (h); EU-Moldova AA 2014, Art.2 (g); EU-Ukraine AA, 2014, Art.2 (d)). It is worth pointing out that these approximation discourses are very often similarly regulated, however Georgia and Moldova see market access and regulatory approximation as the key means to achieve this goal, while Ukraine sets additionally a more ambitious aim - to seek the EU support for the transition to a market economy based upon progressive legislative approximation to the EU law.

Georgia, Moldova and Ukraine have also a similar framework of international commitments in the area on intellectual property rights protection: all of them are WIPO and WTO members, thus the relevant universal regulatory framework is applicable here and is detrimental for the enhancing the cooperation with the EU. After the Soviet Union collapsed in 1991, almost all post-Soviet countries, except Georgia and Ukraine, established the Eurasian Patent Organization in 1994 aiming to ensure the unified protection regime for industrial property. After Moldova ceased its membership in this organization and denounced the Eurasian Patent Convention in 2012, it still has a particular cooperation framework based on the Agreement between Government of the Republic of Moldova and Eurasian Patent Organization on legal protection of inventions on the territory of the Republic of Moldova.

Moreover, these countries differ in their approaches to the implementation of the Association Agreements in their domestic legal order: whereas Georgia and Moldova recognize the direct effect of international treaties on their domestic legal order either on constitutional level (The Constitution of Georgia, 1995, Art. 4 (5)) or in the statutory legislation (Law of Moldova nr. 595-XIV, 1999, Art.20), Ukraine does not follow this pattern and does not recognize the direct effect of international treaties on its national legal system if a treaty is signed and dully ratified by its parliament (The Constitution of Ukraine, 1996, Art.9). As a result, the possibility to apply the Associated 
Agreement provisions directly is very limited in Ukraine and consequently needs legislative efforts to introduce the relevant legal regulation in the national legal system. In broader terms these different approaches towards the general legislative and regulatory approximation discourses in Georgia, Moldova and Ukraine seem also to influence negatively the fulfilment of the Association Agreement implementation in Ukraine, which currently experiences huge backlogs in the rapprochement its legal and regulatory framework to the EU acquis.

The obligation to ensure the intellectual property rights protection by the associated countries is based on extensive legislative and regulatory approximation clauses contained both in the general approximation clauses (EU-Georgia AA, 2014, Art.2 (h); EU-Moldova AA, 2014, Art.2 (g); EUUkraine AA, 2014, Art.2 (d) and a particular subject-matter related regulation (EU-Georgia AA, 2014, Art. 150-202; EU-Moldova AA, 2014, Art.277-332; EU-Ukraine AA, Art. 157-252). They encompass clear provisions on the protection of trademarks, geographical names, producers and performers rights, etc. with the lately regulated framework in the EU-Georgia Agreement and the most detailed regulation in this area in the EU-Ukraine Association Agreement. While fulfilling their commitments based on these provision countries introduce changes to the domestic legislation aimed to strengthen the institutional capacities and enforcement practices. Moreover, all these countries are WIPO and WTO members with the consequence that cooperation in this matter has also the international-law-based track, so that the fulfilment of the obligations under the intellectual property rights protection clauses is also double-checked against the globally recognized commitments in the bilateral relations between the EU and Associated Countries.

The cooperation between the EU and Georgia, Moldova and Ukraine in competition protection is similarly organized: the cooperation between Georgia and the EU contains very fragmented basic regulation aiming to ensure the application of the antitrust and merger legislation, transparency and recognize importance of the competition for trade relations between the parties (EUGeorgia AA, 2014, Art. 203-209) and the standstill rule on subsidies (EUGeorgia AA, 2014, Art. 206). The EU-Moldova Association Agreement contains more precise regulation both on competition protection (EU-Moldova AA, 2014, Art.333-338 AA) and rules on state aid (EU-Moldova AA, 2014, 
Art. 339-344), which lead to the modernization of the competition protection regime in Moldova based on the achievements of the implementation of the Partnership and Cooperation Agreement between the EU and Moldova (Bologan, 2015). The EU-Ukraine Association Agreements contains a detailed regulation on actions as non-compatible with the AA competition provisions (EU-Ukraine AA, 2014, Art.253-261) and prohibited state aid practices (EUUkraine AA, 2014, Art.253 - 261), introducing the elements of the EU-based competition protection regime in the treaty text expressis verbis. As Smyrnova (2017) argues, Ukraine undertook a particular type of commitments in the area of competition protection on alignment of its competition protection legislation to the EU acquis, where the EU acquis scope is defined in the main treaty text with the consequence that the scope of this obligations can be changes while involving the treaty-changing procedures. Moreover, the cooperation between the EU and these countries is also WTO-based, so that international rules on trade and e.g. subsidies, anti-dumping policies etc. come into play as an ultimately recognized international cooperation framework.

The cooperation between the EU and Georgia, Moldova and Ukraine in the consumer protection area is aimed towards two interconnected goals: a high level of consumer protection and the compatibility of the consumer protection systems with the EU requirements, both requiring the adjustment of the regulatory framework in consumer matters of these countries to the EU standards and rules (EU-Georgia AA, 2014, Art.345; EU-Moldova AA, 2014, art.38; EU-Ukraine AA, 2014, art.415). The EU consumer acquis and regulatory practices have become a part of the domestic legal systems of these countries in a most obvious way - through the approximation clauses in the AAs, marking the contractual basis of the extraterritorial application of the EU consumer protection standards in these countries, being based rather on the framework character sectoral regulation unlike in the case of the intellectual property rights protection or the competition protection, as regulated by the Association Agreement between the EU and Ukraine. In consumer protection matters the level of the approximation of the domestic legislation to the EU consumer acquis is different with Moldova being a front-runner with almost fully completed legislative approximation phase. Georgia and Ukraine have rather moderate achievements here: in Ukraine, e.g. the new Consumer 
Protection Act has not been adopted yet, despite the need to renew the legislative regulation is quite high (Holovko-Havrysheva, 2020, p. 78). In Georgia, the renewal of the consumer protection legislation also faces a number of challenges connected to the need to look for compromise between the libertarian approaches towards the development of Georgian economy and the need to ensure social disruptions following from and resulting in very fragmented legislative framework on the consumer protection (Gvelesiani, 2017). The international cooperation in the area of the consumer protection at the universal level, does not seem not to have mandatory rules, unlike in the cases of the intellectual property rights and competition protection, where WIPO and WTO play essential role in shaping the domestic legal regimes in the above-mentioned cases. As a result, the consumer protection globally faces fragmented approaches and practices, being based rather on domestic or regionally developed instruments, where the EU's approach is rather determining the consumer protection policies in the EaP countries.

Thus, even though Georgia, Moldova and Ukraine have a quite similar conventional basis for the regulation of their relations with the EU - the Association Agreements, as this overview analysis shows the scope of obligations of Georgia, Moldova and Ukraine addressing the intellectual property, competition and consumer protection is differently regulated in their association agreements with the EU and thus, leading to the result that the approximation practices applied by the countries and their achievements are different as well. Georgia, Moldova and Ukraine have different levels of the compatibility of their legislation with the EU acquis, with Moldova as a forrunner in the legislative approximation process. However, the biggest challenges these countries face now lies in the area of regulatory approximation, where the domestic administrative practices need to be aligned with the developed legislation and, thus, the EU standards.

\section{EU-Armenia relations in the fields of intellectual property, competition and consumer protection: an overview}

Armenia is the EaP country, where the bilateral relations are regulated on the new type of the partnership and cooperation agreements - Comprehensive 
and Enhanced Partnership Agreement (CEPA, 2017), which reflects the recent achievement in the bilateral cooperation and replaces the partnership and cooperation agreement of 1996 (in force since 1999) which entered into force on 1 March 2021. Armenia, like Belarus, became the member of the Eurasian Union in 2013, so for the development of the cooperation with the EU this fact pointed out the need to discuss the compatibility of the commitments of Armenia with regard to the establishment of the concurring trade regimes under the EEU auspices and arising from the cooperation with the EU. Armenian policy approach trying to bridge the EU and EEU is controversial inside the society and brings rather doubtful political benefits.

Like other EaP countries, except Belarus, Armenia has a unilateral obligation to adjust its domestic legislation under the newly signed partnership and cooperation agreement. As in other cases, the domestic practices on the application of the international legal norms within the country play a crucial role. The constitutional provisions on the international treaties and the application of the international law in the country are detrimental in this case. The constitutional provisions on the international treaties in the country contain rules on the supremacy of the international treaties over the domestic legislation but not the Constitution (the Constitution of the Republic of Armenia, 1995, art. 5(3)); it also provides clear rules on ratification, revocation and suspension of international treaties and contains the prohibition on the ratification of international treaties if they contradict the Constitution (the Constitution of the Republic of Armenia, 1995, art. 116). However, the practices of the constitutional regulation on these issues are similar applied by the EaP countries, thus having as the result insufficient level of the compatibility of the domestic regulations to the internationally agreed rules and standards. The Constitution of Armenia, like constitutions of Ukraine, Belarus, Moldova and Azerbaijan does not contain provisions on direct applicability of international law.

Armenia has also been the member of the Eurasian Patent Organization since 1996, similarly to Belarus and Azerbaijan. The membership in the WIPO and WTO sets also clear lines and principles aiming to enhance intellectual property protection and establish clear and fair-trading rules both for businesses and consumers. 
The competition protection contractual framework contains regulations similar to the provision of the Association Agreement between the EU and Georgia, however has extensive rules on state aid and subsidies (CEPA, 2017, art. 290-296). The competition protection regime of Armenia is based on the legislation on the protection of economic competition of 2002. The consumer protection as a matter of the bilateral cooperation is addressed in very general terms in the treaty itself, providing for gradual approximation between the parties (CEPA, 2017, art. 81-83). The consumer protection regime in the country is based on the Consumer Rights Protection Act of 2001 (Law of Armenia ZR-197, 2001), which reflects the traditional Soviet legacy in the organization of the consumer rights protection regime. The key provisions of the consumer protection legislation of Armenia regulated the basic consumer rights to be protected in real, non-virtual economic relations, therefore there is the need for further amendments to take into consideration the rapid developments in consumer behaviour because of the digitalization of the business life.

The cooperation between the EU and Armenia in the area of the intellectual property rights protection is regulated quite extensively expressis verbis in the text of the new agreement (CEPA, 2017, art. 209-268). As compared to the legislative framework on consumer and competition protection in Armenia, the intellectual property protection regime is developed quite intensively, however the low enforcement of the legislation in all areai is a challenge which undermines the efficiency of the regulatory efforts.

Like in the countries, analyzed before with the exception of Belarus, the efficiency of the cooperation in the areas of the intellectual property rights, competition and consumer protection are linked to the issues of approximation of the legislation and general practices of the implementation of international treaties in Armenia. The general obligation of Armenia to align its legislation to the EU legislation is embedded in the Art. 370 of the CEPA, which reflects the general EU practice of introducing the gradual approximation rhetoric in the treaty text. The CEPA provides rules on the dynamic approximation (CEPA, 2017, art.371) and the approximation monitoring mechanism (CEPA, 2017, art.372-373), which are similar to the Association Agreements regulations. 


\section{Conclusions}

Unlike the intellectual property protection issues, where the international legal framework has been essentially developed since the XIXth century, or the competition protection, where the international legal framework started to develop in the XXth century, the consumer protection issues are paid less attention on the global agenda, that results in the absence of the mandatory international recognized standards for the consumer protection - United Nations Guidelines on Consumer Protection (adopted in 1985 for the first time by the UN General Assembly) are rather soft-law instrument developed to foster the cooperation agenda universally.

Comparing the conventional backgrounds of the cooperation between the $\mathrm{EU}$ and the EaP countries in the presented areas a number of differences with the regard to the scope of the countries obligations and domestic approximation practices can be observed. First of all, it needs to be mentioned that the treatybased regulations on the protection of the intellectual property rights seems to be the priority field of cooperation of the EU with all EaP countries, including Belarus, where the conventional basis for the relation with the EU steams from Soviet times. Moreover, in the cases of the Association Agreements with Georgia, Moldova and Ukraine and the Comprehensive and Enhanced Cooperation Agreement with Armenia the treaty provisions are formulated in a clear and precise manner, opening the possibility of their direct applicability and effect in the domestic legal orders of the states, which recognize direct applicability of international law either on the constitutional level (Georgia) or on the level of the statutory legislation (Moldova).

Secondly, the legal regulation of the cooperation between the EU and the $\mathrm{EaP}$ countries on the competition protection is less precisely regulated as compared to the regulation on the protection of the intellectual property. The consumer protection in any case seems to be the area which is not prioritized on the bilateral relations, so the treaty-based cooperation between the EU and the EaP member states has here the framework character.

Thirdly, although the intensity and scope of the regulations differs both in the subject area and from country to country, the cooperation between the EU and the EaP countries is also dependent on the domestically developed provisions 
and practices with the regard to the implementation of international treaties and approximation of legislation and regulatory practices with exception of Belarus.

Fourthly, all the EaP countries face the acute need to modernize their intellectual property, competition and consumer protection legislation, however in the EaP countries there is competition between EU and EEU regimes, which influences also the approximation debate. Moreover, the scope of their commitments arising from the contractual relations with the EU differs and the practices among the countries deployed to ensure the compatibility of their legislation (besides Belarus) and the real state of the implementation of the relevant treaties in their domestic legal orders also differ.

Thus, the EaP countries in intellectual property, competition and consumer protection are facing the need to develop sound and comprehensive strategies to address these issues, especially taking into consideration the digitalization as a key global trend influencing economy, politics and law.

\section{References}

Agreement between the European Economic Community and the European Atomic Energy Community and the Union of Soviet Socialist Republics on trade and commercial and economic cooperation, OJ L 68, 15.3.1990.

Association Agreement between the European Union and its Member States, of the one part, and Georgia, of the other part, OJ L 261, 30.8.2014.

Association Agreement (2014) between the European Union and its Member States, of the one part, and Moldova, of the other part, OJ L 260, 30.8.2014.

Association Agreement between the European Union and its Member States, of the one part, and Ukraine, of the other part, OJ L 161, 29.5.2014.

Bologan, D. (2015). The adjustment of Moldova's competition law to European Union competition law, Discussion Paper, 1(15), Europa-Kolleg Hamburg, Institute for European Integration, Hamburg. Retrieved on March 23, 2021 from https://www.econstor.eu/bitstream/10419/107195/1/817974261.pdf

Comprehensive and Enhanced Partnership Agreement between the European Union and the European Atomic Energy Community and their Member States, of the one part, and the Republic of Armenia, of the other part, JOIN/2017/037 final - 2017/0238. 
Constitution of Armenia (1995), adopted by referendum on 5 July 1995. Retrieved on March 25, 2021 from> https://www.president.am/en/constitution-2015/

Constitution of Azerbaijan (1995), adopted by referendum on 12 November 1995. Rretrieved on March 25, 2021 from http://ask.org.az/wpcontent/uploads/2019/10/Konstitusiya ENG.pdf

Constitution of Belarus (1994), adopted by Supreme Soviet of Belarus on 15 March 1994. Retrieved on March 25, 2021 from http://law.by/databankbusiness/list-of-legal-acts/?p0=17

Constitution of Georgia (1995), adopted by Parliament of Republic of Georgia on 24 August 1995, Legislative Herald of Georgia, 1995, No.668, Art.31-33.

Constitution of Moldova (1994), adopted by Parliament of Republic of Moldova on 29 July 1994, Monitorul Oficial 1994, No.78, Art.140.

Constitution of Ukraine (1996), adopted by Verkhovna Rada of Ukraine on 28 June 1996, Records of the Verkhovna Rada of Ukraine, 23 July 1996, No 30, Art.141.

Council conclusions on Belarus (2016), retrieved March 25, 2021 from https:/www.consilium.europa.eu/uedocs/cms_data/docs/pressdata/EN/ foraff/122926.pdf

Global Innovation Index, 2020. Rretrieved on March 25, 2021 from https://www.wipo.int/edocs/pubdocs/en/wipo_pub_gii_2020.pdf.

Council Conclusions on Belarus (2016), Press release 61/16. Retrieved on May 2, 2021 from https://www.consilium.europa.eu/en/press/pressreleases/2016/02/15/fac-belarus-conclusions/pdf

Gvelesiani, Z. (2017). The Necessity of Consumer Law for Effective Competition and a More Robust Enforcement of Competition Law. A Comparative Analysis of the EU and Georgian Legal Systems, Dissertation, CEU, Budapest, Hungary.

Holovko-Havrysheva, O. (2020). Legal regulations of the consumer protection in Ukraine with regard to Ukraine's obligation of adaptation to the EU legislation, Przeglad Europejski, 4(4), 61-78.

Hovenkamp, H. J. (2014). Consumer Welfare in Competition and Intellectual Property Law. Faculty Scholarship at Penn Law. 1830. Retrieved on April 27, 2021 from https://scholarship.law.upenn.edu/cgi/viewcontent.cgi?article=2832\&c ontext=faculty_scholarship.

Law of Moldova, nr. 105-XV (2003) on consumer rights protection, Monitorul Official, 2003, No. 126-131, Art.507. (rev. 2018). 
Law of Moldova nr.1453-XII (1993) on consumer rights protection, Monitrul, 1993, No.10.

Law of Moldova, nr. 595-XIV (1999), on international treaties, Monitorul Official, 2020, No. 24-26/137.

Law of the Republic of Armenia nr. ZR-197 (2001) of on the protection of rights of the consumers. Retrieved on March 25, 2021 from http://www.parliament.am/legislation.php?sel=show\&ID=1506\&lang=eng Law of the Republic of Azerbaijan nr. 1113 (1995) on protection of consumer rights of 19 September 1995. Retrieved on March 25, 2021 from https://www.bakinity.biz/upload/docs/consumer.pdf

Law of the Republic of Belarus nr. 94-3 (2013) on the counteraction to monopolistic activities and promotion of competition. Retrieved from https://unctad.org/system/files/official-

Document/ditcclpinf2020d1_en.pdf

Law of the Republic of Belarus nr. 90-z (2002) on consumer protection. Retrieved from https://cis-legislation.com/document.fwx?rgn=1955

Law of Ukraine nr 1023-XII (1991) on consumer rights protection, 1991, Ukrainian Soviet Republic Verkhovna Rada Records, 23 July 1991, No.30, Art.379.

Mathis, J., Sand-Zantman, W. (2015). Welfare Standards in Competition Policy. Retrieved on April 27, 2021 from http://idei.fr/sites/default/files/medias/doc/rap/Welfare_Standard-

Rapport_Final.pdf

Partnership and Cooperation Agreement between the European Union and its Member States, of the one part and the Republic of Azerbaijan, (1996) OJ L 246, 17.9.1999.

Smyrnova, K. (2017). Competition law issues in EU-Ukraine, Moldova \& Georgia Association Agreements (comparative aspects) // Legal Aspects of the EU Association Agreements with Georgia, Moldova and Ukraine in the Context of the EU Eastern Partnership Initiative / A. Trunk; N.Panych; S.Rieckhof, Josef Eul Verlag GmBH: 81-86.

Stazi, A., Mula, D. (2009). Intellectual Property and Consumer Law/ Ramalho Ana, Angelopoulos Christina. Crossroads of Intellectual Property. Intersection of Intellectual Property and Other Fields of Law. Retrieved on April 27, 2021 from https://www.researchgate.net/publication/39728540_Intellectual_Prop erty_and_Consumer_Law

Torti, V. (2018). Intellectual Property and Competition in Standard Setting. Objectives and Tensions, Routledge. 276 p. 